\title{
Based on DPSR Model of Urban Land Intensive Utilization and Regional Urbanization Coordinated Development Evaluation of Space and Time -- A Case Study of the Wuhan City Circle in China
}

\author{
Tian Lixue \\ School of Geography Sciences, South China Normal University, Guangzhou, China \\ Email address: \\ li-xue.tian@m.scnu.edu.cn
}

\section{To cite this article:}

Tian Lixue. Based on DPSR Model of Urban Land Intensive Utilization and Regional Urbanization Coordinated Development Evaluation of Space and Time -- A Case Study of the Wuhan City Circle in China. Earth Sciences. Vol. 4, No. 5, 2015, pp. 211-217.

doi: 10.11648/j.earth.20150405.18

\begin{abstract}
Based on the interaction of urbanization in the urban land intensive utilization and coordination mechanism, this paper constructed the coordination degree between the two and the relative development degree model, quantitative evaluation of urban land intensive utilization and urbanization coordinated development status, and can be divided into low level coordination, antagonism, running-in, high level of coordination of four stages. Using SPSS16.0 and ArcGIS10.0 nine cities of Wuhan city circle the space-time difference of empirical study. The results of the study showed that the coordination degree of status in the stage of low level coordination, antagonism in reducing the number of cities, in the running-in, high level of coordination number of cities is increasing; Based on the relative state development degree, development degree level has been basically assumes the growth tendency, although occasionally there are one or two years a city there are some changes, but can't deny showed a trend of spiral. Relative degree of development of urbanization in the urban land intensive utilization and spatial layout, tend to be reasonable, hand in hand with the development of most cities are in uniform.
\end{abstract}

Keywords: Intensive Utilization of Land, The Urbanization, Coordinated Development Evaluation, Wuhan City Circle

\section{基于DPSR模型下的城市土地集约利用与区域城镇化的时空协调发 展评价一一以中国武汉城市圈为例}

田丽雪

地理科学学院, 华南师范大学, 广州, 中国

邮箱

1i-xue.tian@m.scnu.edu.cn

摘要：基于城市土地集约利用与城镇化的交互协调关系机制，本文构建了两者之间的协调度和相对发展度模型，定量 评价城市土地集约利用与城镇化的协调发展状况, 并将其划分为低水平协调、拮抗、磨合、高水平协调四个阶段。运 用SPSS16.0和ArcGIS10.0 对武汉城市圈九个城市进行时空差异实证研究。研究结果发现, 两者协调度状况处于低水平 协调、拮抗阶段的城市数量在减少, 处于磨合、高水平协调的城市数量在增加; 基于其相对发展度状况, 发展度水平 基本上也在不断呈增长变化趋势, 虽然偶然有一两年某个城市有些许变化, 但是不能否认呈现螺旋上升趋势。城市土 地集约利用与城镇化相对发展度的空间布局也趋于合理, 大多数城市都朝着均匀同步发展。

关键词: 土地集约利用, 城镇化, 协调发展评价, 武汉城市圈 


\section{1. 引言}

随着城市化和工业化进程的加快，土地资源粗放低 效利用和耕地后备资源短缺的现象十分突出。因此, 如 何提高土地使用效率、协调经济发展与耕地保护之间的 矛盾逐渐引起学术界和政府的广泛关注 [1]。对于土地集 约利用的内涵, 本文采用刘浩、张毅、郑文升的观点, 城市土地集约利用是动态相对的, 而不是静态绝对的终 极目标, 即在现有城市化水平下, 通过优化土地结构和 改善土地管理, 在适量增加土地供给前提下, 提高土地 利用效率, 实现经济-社会-生态综合效益最大化的过程 [2]。目前中国关于土地集约利用评价的研究主要集中在 评价内容、评价体系、评价方法等土地集约利用的定量 评价与实证研究 [3-4]。

中国正经历的城市化进程的速度和规模在人类历史 上前所未有, 城市数量和规模迅速增加 [5]。城镇化这一 课题虽然已经过中国学者比较系统、长期深入的研究分析, 仍还有许多具体问题没有得到有效解决 [6]。单一的人口 城市化水平, 只测度了农村人口向城市集中的数量过程, 难以准确反映城市化的丰富内涵, 构造综合测度指标体系 能够更全面、更完整地检测城市化进程, 以期推动中国城 市化健康发展 [7]。

城镇化的适度发展可以推动城市土地的集约利用, 而 城市土地集约利用又可以有效推动城镇化的持续发展, 城 市土地集约利用与城镇化之间存在着一定的耦合关系。一 些学者基于城市化发展规律探讨城市土地集约利用的实践 途径, 研究表明城市土地集约利用与城市化发展阶段密切 相关，应根据城市所处的城市化水平制定土地政策，进行 土地利用规划 [8]。目前很多学者对区域地区的土地集约利 用与经济发展的时空差异进行了一些研究 [9-10], 也为本 文研究城市土地集约与城镇化两者之间的关系提供一些研 究思路和模型参考。但是综合以上相关研究, 关于区域城 市土地集约利用与城镇化化的时空协调关系的研究相对较 少。

本文基于城市土地集约利用与城镇化的协调机制, 以 2006-2011年武汉城市圈九个市州作为研究对象, 构建城 市土地集约利用与城镇化的综合评价指标体系, 采用因子 分析法分别求取城市土地集约利用水平值和城镇化的水 平值, 利用这两个系数构建城市土地集约利用与城镇化协 调度和相对发展度的模型, 并基于SPSS16. 0 和ArcGIS10.0 对武汉城市圈进行时空差异分析。这对城市利用规划和推 动城市的可持续发展有一定的促进作用, 也有助于武汉城 市圈实现 “两型社会” 的目标。

\section{2. 研究方法与过程}

\section{1. 建立评价指标体系}

\subsection{1. 城市土地集约利用评价指标体系}

DPSR框架模型是由PSR模型演化而来的。1993年由欧 洲环境署首次提出 [11], PSR模型的基本内涵是人类活动
给环境和自然资源施加压力 $(\mathrm{P})$, 会改变环境与自然资 源质量的状态 $(S)$ ，人类社会又通过环境、经济、土地 等政策、决策或管理措施对这些状态变化做出响应 (R), 减缓对环境的压力, 实现可持续发展, 它揭示了人类与环 境、资源相互作用的链式因果关系 [12]。与PSR模型相比, DPSR模型增加了 “驱动力” 。驱动力是指造成区域发展环 境变化的原因, 比如经济增长等。

本文采用DPSR框架模型从尽可能多的方面来评价城 市土地集约利用水平, 力求做到更客观更科学。城市土地 集约利用评价指标体系分为目标层、准则层和指标层, 包 括驱动力、压力、状态和响应等指标体系 (表1)。

表1 城市土地集约利用水平评价指标体系。

\begin{tabular}{|c|c|c|}
\hline 目标层 & 准则层 & 指标层 \\
\hline \multirow{13}{*}{$\begin{array}{l}\text { 城市土地集约 } \\
\text { 利用指标体系 }\end{array}$} & \multirow{4}{*}{$\begin{array}{l}\text { 驱动力 (D) } \\
\text { 指标体系 }\end{array}$} & 人均 $G D P S_{1}$ \\
\hline & & GDP增长率 $\mathrm{S}_{2}$ \\
\hline & & 第三产业占GDP比重 $\mathrm{S}_{3}$ \\
\hline & & 城市化率 $\mathrm{S}_{4}$ \\
\hline & \multirow{3}{*}{$\begin{array}{l}\text { 压力 (P) } \\
\text { 指标体系 }\end{array}$} & 建设用地年增长率 $\mathrm{S}_{5}$ \\
\hline & & 城市人口与用地弹性系数 $\mathrm{S}_{6}$ \\
\hline & & 城市人口密度 $S_{7}$ \\
\hline & \multirow{3}{*}{$\begin{array}{l}\text { 状态 (S) } \\
\text { 指标体系 }\end{array}$} & 地均GDP $\mathrm{S}_{8}$ \\
\hline & & 人均道路面积 $\mathrm{S}_{9}$ \\
\hline & & 绿地覆盖率 $\mathrm{S}_{10}$ \\
\hline & \multirow{3}{*}{$\begin{array}{l}\text { 响应 (R) } \\
\text { 指标体系 }\end{array}$} & 地均固定资产投入 $\mathrm{S}_{11}$ \\
\hline & & 地均公用设施投入 $\mathrm{S}_{12}$ \\
\hline & & 地均市容环境卫生投入 $S_{13}$ \\
\hline
\end{tabular}

\subsection{2. 城镇化评价指标体系}

表2 城镇化水平评价指标体系。

\begin{tabular}{l|l|l}
\hline 目标层 & 准则层 & 指标层 \\
\hline & 人口城镇化 & 城镇人口比重 $\mathrm{U}_{1}$ \\
& 第三产业从业人口比重 $\mathrm{U}_{2}$ \\
& 人均 $\mathrm{GDP}_{3} \mathrm{U}_{3}$ \\
& & 人均地方财政收入 $\mathrm{U}_{4}$ \\
& 经济城镇化 & 人均工业总产值 $\mathrm{U}_{5}$ \\
& & 第三产业占GDP比重 $\mathrm{U}_{6}$ \\
城 镇化指 标体 & & 每万人大学生数 $\mathrm{U}_{7}$ \\
系 & & 每万人民用汽车拥有量 $\mathrm{U}_{8}$ \\
& 生活城镇化 & 每万人医院床位数 $\mathrm{U}_{9}$ \\
& & 城镇居民人均可支配收入 $\mathrm{U}_{10}$ \\
& & 人均建成区面积 $\mathrm{U}_{11}$ \\
& & 人均道路面积 $\mathrm{U}_{12}$ \\
& 土地城镇化 & 人均公共绿地面积 $\mathrm{U}_{13}$ \\
\hline
\end{tabular}

城镇化具有多维内涵, 主要包括人口增长、经济发展、 生活提高和土地利用互相联系互相促进的四个方面。综合 相关文献与研究目标 [13], 本文就从人口城镇化、经济城 镇化、生活城镇化和土地城镇化四大层次 13 个指标构建城 市城镇化评价指标体系（表2）。 


\section{2. 评价模型构建}

\subsection{1. 数据标准化}

假设有 $\mathrm{i}$ 个评价城市， $\mathrm{j}$ 个评价指标，构成原始数据矩 阵，每个指标的原始数据值为Xij，即Xij为第 $\mathrm{j}$ 个城市的 第 $\mathrm{i}$ 项指标数据。

由于指标数据具有不同的单位量纲, 为增强指标数据 的可比性, 应进行标准化处理。根据指标数据内涵, 本文 采用级差法进行标准化处理, 如公式 (1)。

\section{$\mathrm{Yij}=(\mathrm{Xij}-\min \mathrm{Xj}) /(\max \mathrm{Xj}-\min \mathrm{Xj})$}

式中, $Y i j$ 为原始数据Xij经过极差标准化后的数据, $\min X j$ 即为 $j$ 城市第 $i$ 项指标数据的最小值, $\max X i j$ 即为 $j$ 城市第 $\mathrm{i}$ 项指标数据的最大值。

\subsection{2. 模型构建}

（1）城市土地集约利用与城镇化综合评价模型

本文采用因子分析法对原始的城市土地集约利用指 标数据和城镇化指标数据中影响较大的因子的权重进行 求取。通过SPSS19.0 对两个评价体系的指标标准数据进行 因子分析, 采用相关性矩阵方法进行分析, 选用最大方差 法进行旋转, 得到相关系数矩阵的特征根及相应的单位特 征向量, 根据特征根的方差贡献率提取累计方差贡献率大 于 $85 \%$ 的前 $\mathrm{K}$ 个的因子, 这些因子即为各指标体系的公共因 子。将标准化后的的数据Yi j 带入式 (2), 求得各个公共 因子得分。

$$
F_{j}=\beta_{j 1} X_{1}+\ldots \ldots+\beta_{\mathrm{jP}} X_{P}
$$

式中, $F_{j}$ 为第 $\mathrm{j}$ 个城市第 $\mathrm{P}$ 个公共因子的因子得分, $\beta_{\mathrm{jP}}$ 为第 $\mathrm{P}$ 个公共因子的引自回归系数。

城市土地集约利用指标评价系统与城镇化指标评价 体系是彼此独立的体系，分别用其各个的公共因子的方差 贡献率作为因子权重。

$$
\begin{aligned}
U_{j} & =a_{1} f_{1}+a_{2} f_{2}+\ldots \ldots+a_{p} f_{p} \\
S_{j} & =b_{1} f_{1}+b_{2} f_{2}+\ldots \ldots+b_{p} f_{p}
\end{aligned}
$$

式中, $U_{j}$ 为城市化水平, $\mathrm{ap}$ 为城镇化评价体系中的 第 $\mathrm{p}$ 个公共因子的方差贡献率, $S j$ 为城市土地集约利用水 平, bp为城市土地集约利用评价体系中第p个公共因子的 方差贡献率。

（2）协调度模型

协调度描述两个或两个以上系统相互作用影响的程度, 由于城市土地集约利用指标体系与城镇化指标体系是两个 彼此独立又相互作用的系统, 本文用下面的协调度公式构 建城市土地集约利用与城镇化的协调度模型, 即式 (4)。

$$
C=(X+Y) / \sqrt{X 2+Y} 2
$$

（3）相对发展度模型

协调度可以描述城市土地集约利用与城镇化的协调 发展水平, 但是却很难评价两者之间的相对发展状况, 故
采用以下公式构建城市土地集约利用与城镇化的相对发 展度系数E, 即式 (5)：

$$
E=U_{i} / S_{i}
$$

\section{3. 协调发展阶段}

根据协调度系数 $\mathrm{C}$, 以及城市集约利用与城镇化的水 平系数（关系程度）, 在论文《城市化与生态环境交互耦 合机制与规律性分析》中参阅区域城市化与生态环境的耦 合协调类型划分标准 [14], 本文按照协调度的水平将城市 土地集约利用与城镇化的协调发展阶段大略分为低水平 协调（I）、拮抗（II）、磨合（III）、高水平协调 (IV) 四个阶段（表3）。

当 $C<-1$, 城市土地集约利用与城镇化的协调发展状态 处于低水平协调阶段, 城市土地集约利用与城镇化的关系 严重失调, 阻碍城市可持续发展, 此时的城市多处于城镇 化初期与城镇化加速期的早期。

当 $-1 \leqslant \mathrm{C} \leqslant 0$, 城市土地集约利用与城镇化的协调发展 状态处于拮抗阶段, 城市土地集约利用与城镇化的关系稍 微失调, 对城市可持续发展有一定的前进障碍, 此时的城 市也多处于城镇化初期与城镇化加速期的早期。

当 $0<C<1$, 城市土地集约利用与城镇化的协调发展状 态处于磨合阶段, 城市土地集约利用与城镇化的关系有点 失调但是趋于优化状态，对城市可持续发展的制约作用减 弱, 此时的城市多处于城镇化加速期的中期与晚期。

当 $1 \leqslant \mathrm{C}$, 城市土地集约利用与城镇化的协调发展状态

\begin{tabular}{|c|c|c|c|}
\hline 协调度系数 & 类型 & 类型特征 & 发展阶段 \\
\hline$C<-1$ & I & $\begin{array}{l}\text { 两者关系严重失调, 制约发 } \\
\text { 展, 系统退化 }\end{array}$ & 低水平协调 \\
\hline$-1 \leqslant C \leqslant 0$ & II & $\begin{array}{l}\text { 两者关系稍微失调, 制约发 } \\
\text { 展, 系统退化 }\end{array}$ & 拮抗 \\
\hline $0<C<1$ & III & $\begin{array}{l}\text { 两者关系趋于优化, 推动发 } \\
\text { 展, 系统优化 }\end{array}$ & 磨合 \\
\hline $1 \leqslant \mathrm{C}$ & IV & $\begin{array}{l}\text { 两者关系处于协调, 影响发 } \\
\text { 展, 系统优化 }\end{array}$ & 高水平协调 \\
\hline
\end{tabular}
处于协调阶段, 城市土地集约利用与城镇化的关系优化协 调, 对城市可持续发展的具有推动作用, 此时的城市多处 于城镇化后期。

表3 城市土地集约利用与城镇化的协调度发展阶段类型。

\section{4. 数据来源及其处理}

数据均来源于湖北省统计年鉴（2007-2012）、中国 城市统计年鉴（2007-2012）、中国环境统计年鉴 （2007-2012）、中国区域经济统计年鉴（2007-2012）、 中国建设统计年鉴（2007-2012）。

\section{3. 实证研究}

\section{1. 研究区状况}

武汉城市圈, 是指武汉及其周边 100 公里范围以内的 黄石、鄂州、黄冈、孝感、咸宁、仙桃、潜江、天门八市, 又称 “ $1+8$ ”。该区域占湖北省 $33 \%$ 的土地和 $51.6 \%$ 的人口, 
城市密集度较高, 经济基础较好, 环境及自然条件优越, 是湖北省乃至长江中游最大的城市圈域。2004年, 武汉城 市圈贡献了湖北省 $59.4 \%$ 的GDP， 65.3\%的财政收入，吸纳 $63.4 \%$ 的投资，承载 $62.5 \%$ 的社会商品零售总额，是湖北经 济实力最强的核心区域。

以武汉为中心的都市密集区优势突出, 与周边资源丰 富、成本竞争力突出的城市群优势互补, 是中国内陆最具 有发展潜力的区域。加快武汉城市圈的建设与发展, 有利 于形成湖北经济发展的强劲增长极、中部地区特别是长江 中游地区经济发展的核心区, 经过努力可以发展成为继沿 海地区之后第四大经济增长极。

\section{2. 评价结果}

因武汉城市圈于 2003 年才初步确定成立, 并且受困于 统计资料的限制, 而且在武汉城市圈成立的初期的几年发 展状态的评价的价值不大，故本文采用2006-2011年位于 武汉城市圈的武汉市、黄石市、鄂州市、孝感市、黄冈市、 咸宁市、仙桃市、潜江市和天门市九个城市的统计数据进 行研究。

依据城市土地集约利用与城镇化综合评价模型, 得到 两个独立指标体系的得分; 根据城市土地集约利用水平和 城镇化水平的协调度模型与相对发展度模型, 得到协调度 系数和相对发展度系数, 以此分析城市土地集约利用与城 镇化时空协调发展状况。

\subsection{1. 城市土地集约利用与城镇化发展水平的时间变化 特征}

由图1来看, 武汉城市圈中土地集约利用水平程度较 高且位于前三甲的城市依次是武汉市、黄冈市、孝感市, 天门市的土地集约利用水平最低。潜江市、鄂州市、黄石 市土地集约利用水平变化相对较缓。黄冈市、仙桃市、咸 宁市在土地集约利用水平的变化过程中都出现较明显的 拐点, 黄冈市土地集约利用水平在 2007 年明显下降, 但是 随后又增长至较高水平; 仙桃市从 2007 年开始土地集约利 用水平呈缓慢下降状况，2009年以后又开始慢慢增长; 咸 宁市2006-2008年土地集约利用水平发展较平缓，从2009 年开始由于政府政策改变, 土地集约利用水平增加明显。

总体而言，2006年-2011年武汉城市圈大部分城市的 城镇化发展水平较为平缓, 由图2来看, 很明显, 武汉市 的城镇化水平最高, 一直处于前列, 黄石市的城镇化水平
也处于前列且变化较平缓, 天门市的城镇化水平最低且发 展均匀。咸宁市、孝感市、仙桃市、潜江市的城镇化水平 依次排列发展相对平缓。鄂州市、黄冈市城镇化发展的过 程中出现明显的拐点, 黄冈市在 2010 年的城镇化水平增长 最快; 鄂州市在这几年中城镇化水平变化最大, 除了在 2007年和 2010 年下降外, 呈现很强烈的上涨趋势, 并在 2011年城镇化水平跃居武汉城市圈第二。

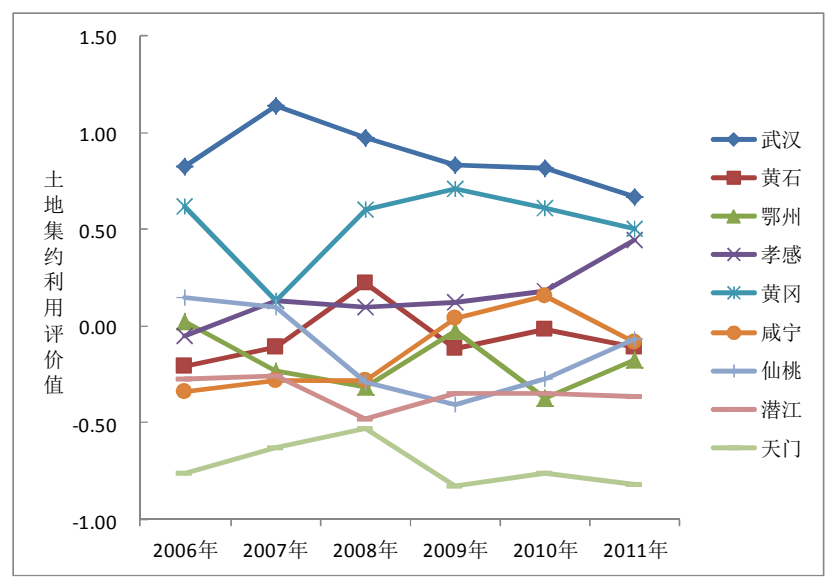

图1 武汉城市圈2006年-2011年土地集约利用评价结果。

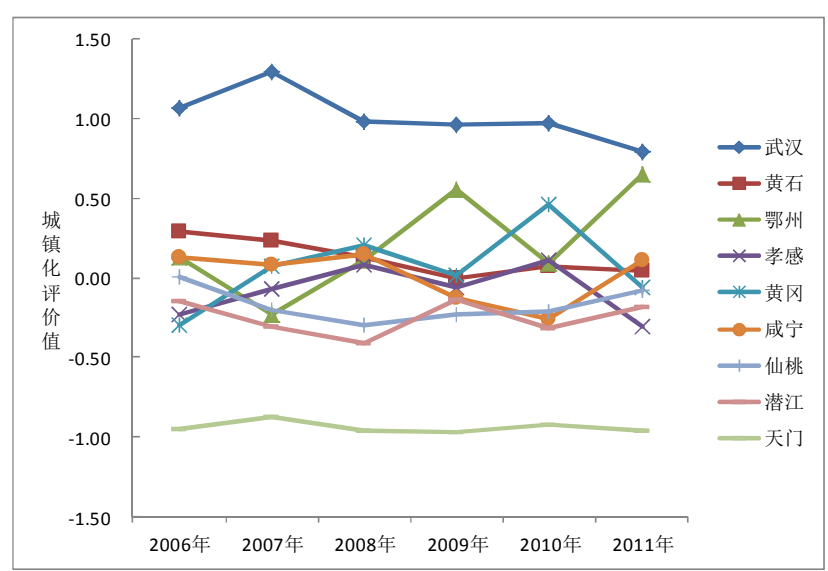

图2 武汉城市圈2006年-2011年城镇化评价结果。

表4 武汉城市圈城市土地集约利用与城镇化协调度系数评价。

\begin{tabular}{|c|c|c|c|c|c|c|c|c|c|c|c|c|}
\hline \multirow{2}{*}{ 城市 } & \multicolumn{2}{|l|}{ 2006年 } & \multicolumn{2}{|l|}{ 2007年 } & \multicolumn{2}{|l|}{ 2008年 } & \multicolumn{2}{|l|}{ 2009年 } & \multicolumn{2}{|l|}{ 2010年 } & \multicolumn{2}{|l|}{ 2011年 } \\
\hline & 协调度系数 & 类型 & 协调度系数 & 类型 & 协调度系数 & 类型 & 协调度系数 & 类型 & 协调度系数 & 类型 & 协调度系数 & 类型 \\
\hline 武汉 & 1.40 & IV & 1.41 & IV & 1.41 & IV & 1.41 & IV & 1.41 & IV & 1.41 & IV \\
\hline 黄石 & 0.23 & III & 0.49 & III & 1.37 & IV & -1.03 & I & 0.80 & III & -0.54 & II \\
\hline 鄂州 & 1.17 & IV & -1.41 & I & -0.60 & II & 0.96 & III & -0.74 & II & 0.71 & III \\
\hline 孝感 & -1.20 & I & 0.38 & III & 1.41 & IV & 0.48 & III & 1. 37 & IV & 0.25 & III \\
\hline 黄冈 & 0.46 & III & 1.36 & IV & 1.27 & IV & 1.02 & IV & 1. 40 & IV & 0.87 & III \\
\hline 咸宁 & -0.58 & II & -0.69 & II & -0.42 & II & -0.64 & II & -0.35 & II & 0.18 & III \\
\hline 仙桃 & 1.02 & IV & -0.45 & II & -1.41 & I & -1.36 & I & -1.40 & I & -1.41 & I \\
\hline 潜江 & -1.36 & I & -1.41 & I & -1.41 & I & -1.30 & I & -1.41 & I & -1.34 & I \\
\hline 天门 & -1.41 & I & -1.40 & I & -1.36 & I & -1.41 & I & -1.41 & I & -1.41 & $\mathrm{I}$ \\
\hline
\end{tabular}




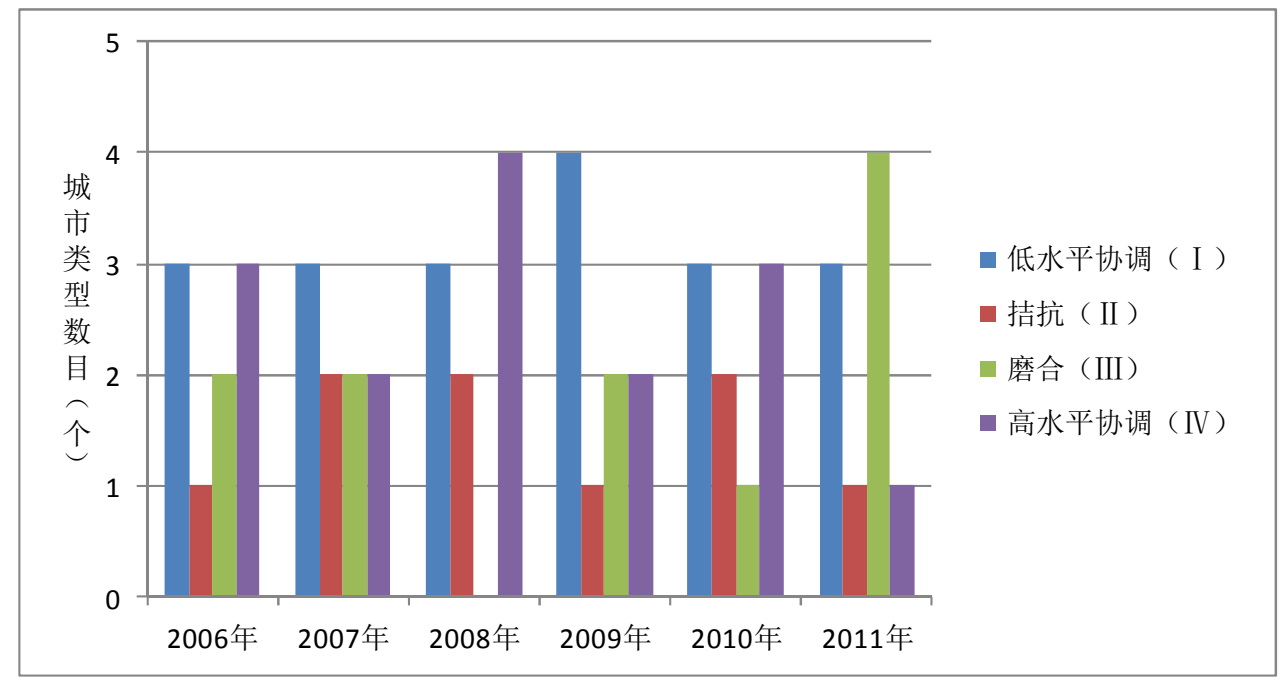

图3 武汉城市圈城市土地集约利用与城镇化的协调度关系状况。

本文按照协调度的水平将城市土地集约利用与城镇 化的协调发展阶段大略分为低水平协调( I )、拮抗 ( II )、 磨合（III）、高水平协调（IV）四个阶段。由表4, 可看 出2006年-2011年武汉城市圈九个城市的具体的协调发展 类型。

武汉城市圈城市土地集约利用与城市化的协调度关 系状况处于低水平协调（I）、拮抗（II）、磨合（III）、 高水平协调 (IV) 四个阶段。由图3可见，2006年3市为低 水平协调 3 市为高水平协调, 1 市为拮抗阶段, 2 市为磨合 阶段； 2007 年3市为低水平协调，拮抗、磨合、高水平协 调阶段均有 2 市; 2008 3市为低水平协调, 2 市为拮抗阶段, 而高水平协调有4市，没有磨合阶段；2009年4市为低水平 协调， 1 市为拮抗阶段，磨合、高水平协调阶段均有 2 市; 2010年低水平协调、高水平协调阶段均有 3 市， 2 市为拮抗 阶段，1市为磨合阶段；2011年拮抗、高水平协调阶段各 有1市, 3 市低水平协调, 而高水平协调阶段此时最多, 有 4市。武汉城市圈地区协调关系不断提高, 磨合 (III)、 高水平协调 (IV) 阶段的城市数量呈增加趋势, 城市土地 集约利用与城镇化的协调状况得到优化。

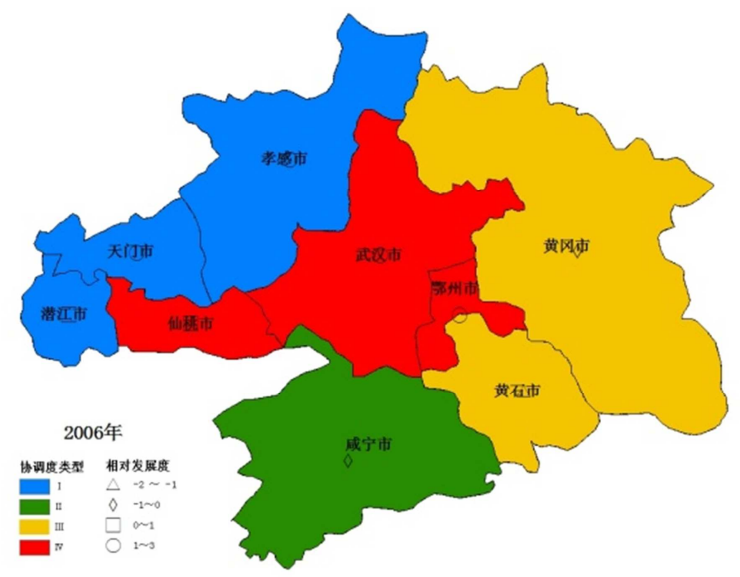

\section{2. 2. 城市土地集约利用与城镇化协调度、相对发展度 的空间差异特征}

本文利用2006年-2011年武汉城市圈9个市州城市土 地集约利用、城镇化水平以及两个的协调度和相对发展度 评价值, 运用ArcGIS中的分类方法进行评价水平等级的划 分, 得出武汉城市圈城市集约利用与城镇化协调度、相对 发展度的空间布局特征, 如图4所示。

由图4可见，武汉市无论是城市土地集约利用与城镇 化协调关系还是相对发展度关系均在武汉城市圈位列前 茅, 且与其他市州的差距较大。就城市土地集约利用与城 镇化协调关系来看, 黄冈市、孝感市、黄石市相对比较高, 咸宁市、鄂州市水平较低, 仙桃市、潜江市、天门市这三 个省直辖的县级市水平最低。在地域上呈现由中间向四周 递减的状态, 中间的武汉最高, 其次是东部和北部, 再次 是南部, 西部最低。就城市土地集约利用与城镇化相对发 展度关系来看, 仙桃市、潜江市、天门市这三个省直辖的 县级市水平较高, 其次是黄冈市、孝感市、鄂州市, 咸宁 市、黄石市相对比较低; 在地域上呈现由中部和西部相对 一直较高, 向东部、北部、南部递减的状态。

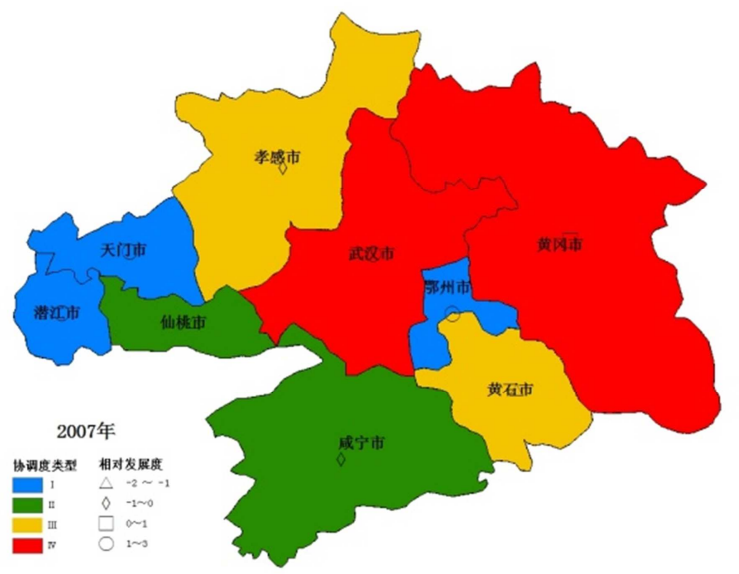



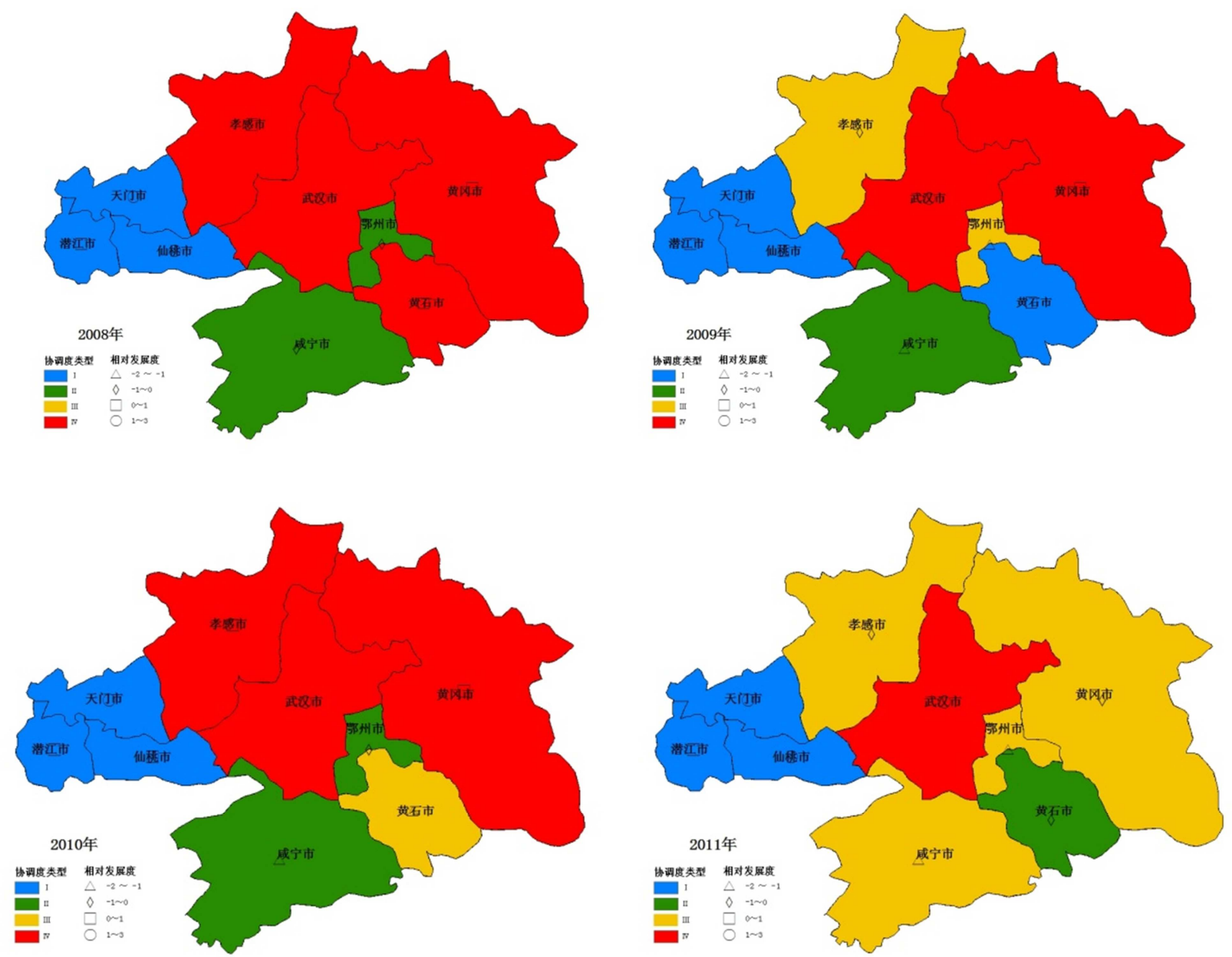

图4 武汉城市圈协调度关系类型与相对发展度的空间差异状况。

\section{4. 结论与讨论}

(1) 城市土地集约利用与城镇化之前存在着一定的 协调关系，区域内部不同的市州由于城镇化发展水平不同， 其土地集约利用也会因土地利用投入、强度和用途等存在 着差异。研究城市土地集约利用与城镇化两者之前的协调 度关系和相对发展度关系状态对于城市利用规划和推动 城市的可持续发展有着很重要的参考价值。

(2) 本文将武汉城市圈九个城市的城市土地集约利 用与城镇化的协调关系分成低水平协调 (I)、拮抗 (II)、 磨合 (III) 、高水平协调 (IV) 四个阶段, 随着时间变化, 处于低水平协调（I）、拮抗（II）阶段的城市数量在减 少，而处于磨合（III）、高水平协调（IV）阶段的城市数 量呈现不断上升趋势。武汉城市圈九个城市的城市土地集 约利用与城镇化相对发展度水平基本上也在不断呈增长 变化趋势, 虽然偶然有一两年某个城市有些许变化, 大多 也是因为政策倾向原因所影响, 仍呈现螺旋上升趋势。城 市土地集约利用与城镇化相对发展度的空间布局也趋于 合理, 大多数城市都朝着均匀同步发展。

(3) 由于统计数据的限制, 以及研究区域特殊的发 展状况, 武汉城市圈成立发展的时间尚短, 而且武汉发 展比其他地区各方面的差距较大, 对本文做次研究也有
一定的难度, 难免存在一定的缺陷和不足, 研究数据和 评价模型还可进一步完善。在此申明, 由于模型及体系 都在武汉城市圈这个范围内测算的一个相对的分数, 并 无与其他地区相比的意思, 只用于分析区域内部的相对 发展的一个指标。

\section{致谢}

基金项目：国家自然科学基金（41571187）资助。

\section{参考文献}

[1] 邓超. 武汉市耕地集约利用评价研究 [D]. 武汉:华中农业大 学, 2010:14-15。

[2] 刘浩, 张毅, 郑文升. 城市土地集约利用与区域城市化的时 空耦合协调发展评价一以环渤海地区城市为例 [J]. 地理研 究, 2011, 30 (10) : 1805-1817。

[3] 冯科, 郑娟尔, 韦仕川, 等. GIS和PSR框架下城市土地集约利 用空间差异的实证研究一以浙江省为例 $[\mathrm{J}]$. 经济地 理, 2007, 27 (5):811-814。 
４4］李进涛, 谭术鬼, 汪文雄. 基于DPSIR模型的城市土地集约利 用时空差异的实证研究一以湖北省为例. 中国土地科 学, 2009, 23 (3) : 49-54。

[5] Roger C k, Yao shimou. Urbanization and sustainable metropolitan development in China: Patterns problems and prospects. GroJournal, 1999, 49: 269-277.

[6] 仇保兴. 实现我国有序城镇化的难点与对策选择. 城市规划 学刊, 2007, (5) : 1-15。

[7] 陈明星, 陆大道, 张华. 中国城市化水平的综合测度及其动 力因子分析 [J]. 地理学报, 2009, 64 (4) : 387-398。

［8］毛蒋兴, 间小培, 王爱民. 20 世纪90年代以来我国城市土地 集约利用研究述评. 地理与地理信息科 学, 2005, 21 (2) : 48-57。

［9］李昌峰, 武清华, 张落成. 土地集约利用与经济发展的空间 差异研究一以长江三角洲地区为例 [J]. 经济地 理, 2011, 31 (2):294-299。
[10] 潘竟虎, 郑风娟, 杨东. 甘肃省土地集约利用与经济发展的 时空差异分析 [J]. 资源科学, 2011, 33 (4) :684-689。

[11] Svarstada H., Petersenb LK, Rothmanc D., et al. Discursive biases of the environmental research framework DPSIR[J]. Land Use Policy, 2008, 25(1): $116-125$.

[12] Gerven T. Van, Block C., Geens J., et al. Environmental response indicators for the industrial and energy sector in Flanders [J]. Journal of Cleaner Production, 2007, $15(10): 886-894$.

[13] 郝华勇. 基于主成分分析法的武汉城市圈城镇化质量实证 研究 $[J]$. 武汉科技大学学报, 2012, 14 (3) :291-294。

[14] 黄金川, 方创琳. 城市化与生态环境交互耦合机制与规律性 分析 [J]. 地理研究, 2003, 22 (2) : $211^{\sim} 220$ 。 